\title{
OPTIMALISASI LAHAN PERKEBUNAN KELAPA SAWIT (Elaeis guineensis Jacq.) DAN JAGUNG (Zea Mays Saccharata, Sturt)
}

\author{
*Rizki Kurniawan \\ Program Studi Agribisnis, Fakultas Pertanian, Universitas Lancang kuning. \\ Jalan Yos Sudarso KM. 8 Rumbai Pekanbaru - Riau
}

\begin{abstract}
ABSTRAK
Mengusahakan tanaman pangan, perkebunan, dan hortikultura sebagai tanaman sela di antara kelapa sawit sangat berpeluang untuk dilakukan. Dalam melakukan tanam sela perlu disesuaikan dengan sumber daya dan permintaan pasar. Sumber daya yang dimaksud berupa kondisi lahan dan iklim, kondisi tanaman kelapa sawit, dan status teknologi, sedang bentuk usahataninya ditentukan oleh sosial budaya dan ekonomi petani, serta permintaan pasar. Faktor kesesuaian iklim merupakan faktor utama yang harus diperhatikan dalam menentukan pemilihan tanaman sela, sedangkan tingkat kesuburan tanah dapat dimodifikasi dengan perlakukan khusus.
\end{abstract}

Kata Kunci : Jagung, Kelapa sawit,Optimalisasi Lahan

\section{PENDAHULUAN}

Komoditi kelapa sawit merupakan komoditi perkebunan utama yang dikembangkan oleh pemerintah Provinsi Riau, beberapa alasan mengapa pemerintah Provinsi Riau mengutamakan kelapa sawit yaitu ditinjau dari segi fisik dan lingkungan, keadaan daerah Riau memungkinkan untuk pengembangan perkabunan kelapa sawit, ditinjau dari kondisi tanah yang memungkinkan untuk ditanami kelapa sawit dan menghasilkan produksi lebih tinggi dibandingkan daerah lain, ditinjau dari segi pemasaran hasil produksi daerah Riau mempunyai keuntungan karena letaknya sangat strategis dengan pasar internasional yaitu Singapura, daerah Riau juga merupakan daerah pengembangan Indonesia Bagian Barat dengan dibukanya kerjasama Indonesia Malaysia Singapore Growth Triagle IMT-GT, dan 
berdasarkan hasil yang telah dicapai menunjukkan bahwa kelapa sawit memberikan pendapatan yang lebih tinggi kepada petani diabandingkan dengan jenis tanaman perkebunan lainnya.

Untuk mendapatkan hasil buah yang baik tanaman kelapa sawit membutuhkan waktu 5-7 tahun. Bibit kelapa sawit dapat di tanam di lahan perkebunan ketika usia bibit mencapai 6 sampai dengan 18 bulan. Rentang waktu setelah ditanam sampai dengan masa panen yaitu 34 tahun. Tanaman kelapa sawit memiliki jarak yang cukup lebar yaitu 9m x 9m, 9m x 8m, 8m x $8 \mathrm{~m}$ ukuran ini disesuaikan dengan jenis tanaman sawit pelepah panjang atau sawit pelepah pendek. Hal ini memungkinkan untuk membudidayakan lebih dari satu tanaman dalam suatu waktu tertentu.

Penanaman dengan sistem tumpang sela dapat meningkatkan efesiensi penggunaan faktor lingkungan (seperti cahaya unsur hara air), tenaga kerja, menurunkan serangan hama dan penyakit serta menekan pertumbuhan gulma. Jagung merupakan tanaman semusim yang dapat dijadikan sebagai tanaman sela pada perkebunan kelapa sawit. Dengan adanya pola tumpang sela ini memungkinkan pendapatan tambahan bagi petani selama kelapa sawit belum menghasilkan.

\section{TINJAUAN PUSTAKA}

Salah satu masalah utama komoditas kelapa sawit Indonesia adalah rendahnya produktivitas tanaman, terutama untuk bentuk usaha perkebunan rakyat (PR). Produktivitas tanaman kelapa sawit saat ini pada Perkebunan Rakyat adalah 5 ton TBS/ha/tahun, sedangkan pada Perkebunan Besar sudah mencapai $>20$ ton TBS /ha/tahun. Tingkat produktivitas yang dicapai perkebunan kelapa sawit Indonesia ini masih berada di bawah potensi produktivitasnya yang mampu menghasilkan 25-30 ton TBS/ha/tahun. (Herman, 2011)

Rendahnya produktivitas tanaman kelapa sawit Indonesia ini disebabkan oleh banyak faktor. Faktor utama adalah masih dominannya tanaman yang dikelola dengan penggunaan teknologi dan manajemen sederhana serta diusahakan dengan skala kecil. Salah satu upaya untuk meningkatkan produktivitas tanaman kelapa sawit Indonesia adalah melalui peremajaan. Namun tingginya biaya untuk melakukan peremajaan (25-30 juta rupiah per hektar) menyebabkan pertanaman kelapa sawit rakyat sangat sulit untuk diremajakan, sedangkan tanpa peremajaan produktivitas kelapa sawit secara nasional akan terus menurun. (Herman, 2011) 
Cara lain untuk menjamin kontinuitas pendapatan adalah dengan menanam tanaman sela sebelum tanaman kelapa sawit menghasilkan. Penanaman jagung sebagai tanaman sela diantara tanaman perkebunan sering dilakukan petani untuk pemanfaatan lahan yang tersedia, terutama pada tanaman pokok yang belum menghasilkan (Herman, 2011).

Produktivitas optimal merupakan tujuan utama atas setiap usaha pertanian, teknologi pemupukan yang dilengkapi ZPT (Zat Pengatur Tumbuh Tanaman) akan mempengaruhi produksi jagung sesuai dengan hasil penelitian (Surtinah, et al., 2012) terjadi peningkatn berat tongkol berkelobot sebesar 9,24\%, Berat tongkol berkelobot jagung manis pada penelitian yang tidak menggunakan pupuk hayati dan ZPT dilaporkan hanya mampu memperoleh berat tongkol tanpa kelobot tertinggi adalah 372,19 gram. Takaran paket pupuk dan ZPT yang tepat akan memberikan hasil yang terbaik. Sedangkan pada konsentrasi yang lebih tinggi untuk paket pupuk dan ZPT yang diberikan justru menyebabkan penurunan hasil (Surtinah, 2017).

Jenis tanah di Riau didominasi oleh Podsolik Merah Kuning (PMK) yang dikenal mengandung sedikit unsur hara, sedikit mengandung bahan organik, dan $\mathrm{pH}$ yang rendah (Surtinah, 2012)

\section{HASIL DAN PEMBAHASAN}

Perkebunan kelapa sawit di indonesia diusahakan dalam bentuk perkebunan besar swasta maupun pemerintah yang dikelola dengan manajemen yang baik dan memiliki tujuan yang diorentasikan pada pemenuhan kebutuhan pasar, baik pasar dalam negeri dan luar negeri. Sementara itu perkebunan rakyat umumnya dikelola dengan manajemen seadanya dan masih bersifat tradisional. Begitu juga dengan penerapan teknologi tanaman sela walaupun telah sejak lama dan umum dilakukan di tingkat petani tetapi tujuannya semata mata hanya untuk memenuhi kebutuhan sehari-hari keluarga petani atau masih bersifat subsisten.

Di Provinsi Riau program peremajaan sawit rakyat dilaksanakan pada bulan februari 2018 yang tersebar di Lima Kabupaten yaitu Rokan Hulu, Rokan Hilir, Kampar, Siak, Pelalawan. Peremajaan sawit ini sangat penting guna untuk meningkatkan produktivitas, ada 2,7 juta hektare kebun kelapa sawit yang perlu diremajakan dari total 4,7 juta hektare kebun kelapa sawit rakyat. Pada masa peremajaan banyak lahan yang tidak produktif, Oleh karena itu, 
pemanfaatan lahan tidak produktif tersebut secara optimal untuk produksi jagung merupakan strategi yang sangat esensial.

Pola tumpang sela kelapa sawit - jagung dapat dilakukan saat awal fase pertumbuhan kelapa sawit sampai batas naungan maksimal $70 \%$ atau sekitar umur sawit empat tahun. Selain di perkebunan sawit, tanaman jagung dapat diintegrasikan dengan pola tumpang sari di lahan perkebunan karet, kelapa, dan jambu mete. (T3).

Hasil penelitian menunjukkan bahwa penanaman tanaman sela jagung tidak mempengaruhi pertumbuhan tanaman kelapa sawit muda sebagai tanaman pokoknya, bahkan secara ekonomi dapat menambah keuntungan B/C ratio antara 1,30-2,05( (Purba, 1998). Keuntungan lain yang didapat dari tumpang sela ini adalah menunjang keberlanjutan usaha pertanian melalui maksimalisasi penggunaan lahan, stabilitas hasil dan keuntungan.

Tanaman jagung dapat tumbuh pada hampir semua jenis tanah mulai dengan tekstur berpasir hingga tanah liat, akan tetapi jagung akan tumbuh baik pada tanah yang gembur dan kaya akan humus dengan tingkat keasaman $(\mathrm{pH})$ tanah antara 5,5 - 7,5. Pedsolik Merah Kuning (PMK) merupakan tanah yang mendominasi di Riau. Potensi tanah podzolik merah kuning untuk tanaman perkebunan seperti Sawit, Karet, dan Hutan tanaman industri terbukti mampu meningkatkan produktivitas tanaman yang baik, namun untuk tanaman pangan seperti Jagung memerlukan penanganan yang khusus.

Penambahan unsur hara yang berasal dari bahan organik belum cukup untuk meningkatkan produktifitas jagung. Pengapuran merupakan cara yang cepat untuk menaikkan nilai $\mathrm{pH}$ tanah yang rendah. Pemberian kapur selain memperbaiki nilai $\mathrm{pH}$ tanah, juga menambah unsur $\mathrm{Ca}$, $\mathrm{Mg}$, ketersediaan $\mathrm{P}$ dan Mo serta mengurangi keracunan yang disebabkan oleh $\mathrm{Al}$, Fe dan Mn. Peingkatan produktifitas tanaman jagung bisa dilakukan dengan teknologi pemupukan yang dilengkap ZPT( Zat Pengatur Tumbuh Tanaman).

\section{KESIMPULAN}

Tanaman produktif jagung ini bisa ditanam di sela sawit mulai dari Tumbuhan Belum Menghasilkan (TBM) hingga usia 3 tahun atau tanaman menghasilkan (TM1). Dengan meningkatkan aktivitas usaha tani perkebunan secara cerdas dan tepat sesuai inovasi teknologi, akan terjadi peningkatan produksi dan pendapatan. 
Kesesuaian iklim merupakan salah satu pertimbangan utama dalam memilih jenis tanaman tumpang sela (jagung), jenis tanah PMK yang mendominasi di Riau harus di berikan penanganan khusus untuk meningkatkan produktifitas jagung dengan cara penambahan unsur hara yang berasal dari bahan organik, pemberian kapur.

\section{DAFTAR PUSTAKA}

Herman M., Pranowo, D. PRODUKTIVITAS JAGUNG SEBAGAI TANAMAN SELA PADA PEREMAJAAN SAWIT RAKYAT DI BAGAN SAPTA PERMAI RIAU [Jurnal]. - Sukabumi : Balai Penelitian Tanaman Rempah dan Aneka Tanaman Industri, 2011.

L Karimuna. S Safitri., Ode I. Pengaruh Jarak Tanam dan Pemangkasan terhadap Kualitas Silase Dua Varietas Jagung (Zea mays L.) [Jurnal]. - 2009. - hal. 17.

Purba A., P. Girsang, W. Dharmosarkoro dan Z. Poeloengan Corn as an intercropping in immature oil palm plantation [Jurnal] // Journal of Indonesia Oil Palm Research Institute. - 1998. - Vol. 6(1). hal. 29-36.

Surtinah dan Lidar S Pertumbuhan Vegetatif dan Kadar Gula Biji Jagung Manis (Zea mays saccharata, Sturt) di Pekanbaru. [Jurnal] // Jurnal IImiah Pertanian. - 2012. - Vol. 13(2). - hal. 73-78.

Surtinah dan Lidar, S. Pertumbuhan Vegetatif dan Kadar Gula Biji Jagung Manis (Zea mays saccharata, Sturt) di Pekanbaru [Jurnal] // J.Ilmiah Pertanian. - Pekanbaru : [s.n.], 2012. - Vol. 13(2). hal. 73-78.

Surtinah Potensi Hasil Jagung Manis (Zea mays saccharata, Sturt) dengan Pemberian Paket Teknologi Pupuk dan Zat Pengatur Tumbuh [Jurnal] // Jurnal Bibiet 2. - Maret 2017. - hal. 37-44. 